\title{
Etiologia viral de infección respiratoria aguda en niños menores de 5 años en las provincias Comunera $y$ Garcia Rovira de Santander
}

\section{Etiology of acute respiratory infection in children under 5 years in the provinces Comunera and Garcia Rovira of Santander}

Jorge R. García Corzo ${ }^{1}$, Jurg Niederbacher Velasquez ${ }^{1}$, Clara I. González Rugéles ${ }^{1}$, Laura A. Rodríguez Villamizar ${ }^{1}$, Mayra Machuca Pérez ${ }^{1}$, Alexander Torres Prieto², Gloria C. Ortiz Rodríguez², Mónica Romero Salazar ${ }^{2}$

Forma de citar: García Corzo JR, Niederbacher Velasquez J, González Rugéles CI, Rodríguez Villamizar LA, Machuca Pérez M, Torres Prieto A, et al. Etiología viral de infección respiratoria aguda en niños menores de 5 años en las provincias Comunera y García Rovira de Santander. Rev Univ Ind Santander Salud. 2016; 48(2): $240-245$. DOI: http://dx.doi.org/10.18273/revsal.v48n2-2016009 @) (1)

\section{RESUMEN}

Introducción: La infección respiratoria aguda es una causa importante de morbimortalidad en menores de cinco años en los municipios de las provincias de Santander. La etiología viral en esos municipios no es bien conocida. Objetivo: El objetivo del estudio fue determinar la etiología viral de la infección respiratoria aguda en menores de cinco años en las provincias Comunera y García Rovira del departamento de Santander entre diciembre de 2012 y diciembre de 2013. Materiales y métodos: Estudio descriptivo en población usuaria de servicios de urgencias. Se obtuvieron muestras por hisopado nasofaríngeo y se realizó amplificación por reacción en cadena de polimerasa con el test Seeplex ${ }^{\circledR}$ RV15 OneStep ACE Detection, multiplex para 15 virus. Resultados: Participaron 64 niños, 57,8\% niños de sexo masculino. El 26,6\%, de los niños eran menores de un año. La positividad para virus fue del 37,5\% de las muestras. El $75 \%$ de las muestras positivas fueron de la provincia Comunera y $25 \%$ de la provincia de García Rovira. Hubo co-infección por dos virus en $8,3 \%$ de las muestras positivas. Los virus más identificados fueron Rhinovirus (29\%), Parainfluenza 4 (20,8\%) e Influenza (12,5\%). También se identificó Coronavirus, Adenovirus, Virus Sincitial Respiratorio, Metapneumovirus y otros virus Parainfluenza. Conclusiones: En las dos provincias de Santander evaluadas circula una amplia cantidad de virus respiratorios en menores de cinco años. El Rhinovirus fue identificado como el más frecuente. Se encontró presencia de Metapneumovirus y Coronavirus humano.

Palabras claves:Virus, infecciones del sistema respiratorio, niño, prevalencia, reacción en cadena de la polimerasa multiplex.

1. Universidad Industrial de Santander. Bucaramanga, Colombia.

2. Secretaría de Salud Departamental, Gobernación de Santander. Bucaramanga, Colombia

Correspondencia: Jorge Raúl García Corzo. Dirección: Clínica Chicamocha. Carrera 46 64-07 La Floresta, Bucaramanga. Correo electrónico: jrgarciacor@gmail.com. Teléfono: 3002222923 


\section{ABSTRACT}

Introduction: Acute respiratory infection is a major cause of morbidity and mortality in children under 5 years in Santander (Colombia). Viral etiology in municipalities from this department is not well known. Objective: To determine the viral etiology of acute respiratory infection in children under five years in the provinces Comunera and García Rovira (Santander) from December 2012 to December 2013. Methodology: Descriptive study in pediatric population who attended the emergency services studied. Nasopharyngeal swab samples were obtained and a polymerase chain reaction was performed with Seeplex ${ }^{\circledR}$ OneStep RV15 ACE Detection, which is a multiplex test for 15 virus. Results: 64 children were enrolled, $57,8 \%$ being boys. $26.6 \%$ of participants were under one year. Virus positivity was present in $37.5 \%$ of the samples and $75 \%$ of the positive samples were from the province Comunera. Besides, $8.3 \%$ from positive samples were co-infected with two viruses. The most common virus were Rhinovirus (29\%), Parainfluenza 4 (20.8\%) and influenza (12.5\%). Coronavirus, Adenovirus, respiratory syncytial virus, Metapneumovirus and other Parainfluenza virus were also identified. Conclusions: There is a wide circulation of respiratory virus in children under five in these two provinces of Santander (Colombia). Rhinovirus was the most frequent. Human Metapneumovirus and Coronavirus were also found.

Keywords: Viruses, respiratory tract infections, child, prevalence, multiplex polymerase chain reaction.

\section{INTRODUCCIÓN}

La infección respiratoria aguda (IRA) sigue siendo una de las mayores causas de morbimortalidad infantil, de hecho, las infecciones respiratorias bajas son la primera causa de muerte entre 1 y 59 meses de edad a nivel mundial ${ }^{1}$. Según el Observatorio de Salud Pública de Santander, en el año 2011 a nivel departamental, los distintos tipos de IRA juntos, fueron la primera causa de consulta externa en menores de un año $(19,8 \%)$ y de uno a cuatro años $(9,8 \%)$. En cuanto a consulta de urgencias, fueron la primera causa en menores de un año $(20,8 \%)$ y la segunda de uno a cuatro años (10,5\%). Las provincias distintas a la capital aportaron el $41,8 \%$ del total de registros de IRA. Las provincias Comunera y GarcíaRovira aportaron el 3,3\% y 7,3\% del total de casos reportados, respectivamente ${ }^{2}$.

En las provincias Comunera y García-Rovira, no existe información acerca de los virus causantes de IRA en menores de cinco años. Esta información es importante para mejorar el conocimiento sobre los virus causantes que circulan fuera de la capital Santandereana y planear actividades de prevención relacionadas con el programa ampliado de inmunización.

El objetivo de este estudio fue determinar la presencia de 15 virus respiratorios en menores de cinco años con diagnóstico clínico de IRA en la provincia Comunera y en la provincia de García Rovira durante el periodo entre diciembre 2012 y diciembre de 2013.

\section{MATERIALES Y MÉTODOS}

\section{Diseño del estudio}

Se realizó un estudio descriptivo prospectivo en niños menores de cinco años de edad con diagnóstico de infección respiratoria aguda (IRA) dado por un médico en el servicio de urgencias. Se obtuvo financiación para 64 muestras y procesamientos que se distribuyeron de manera proporcional a la población de cada provincia. Los sitios donde se realizó el muestreo fueron la provincia Comunera (Hospital Regional Manuela Beltrán del Socorro) y la provincia de García Rovira (Hospital Regional de Málaga, Hospital Santa Ana de Guaca y Hospital San Antonio del Cerrito). Estas instituciones fueron seleccionadas porque atienden población rural y urbana, además brindan atención tanto a pacientes externos como a pacientes que requieren hospitalización. Socorro y Málaga son los principales municipios de estas provincias y dado el importante porcentaje de IRA aportado por García Rovira, se asignaron otros tres municipios a esta provincia. La Secretaría de Salud Departamental convocó a las instituciones seleccionadas para participar en el proyecto. Para evitar que los virus aislados solo representaran un pico de infección respiratoria, las muestras se tomaron de forma uniforme a lo largo de un año.

\section{Características geográficas y climáticas}

La provincia Comunera está conformada por 17 municipios siendo El Socorro su capital, con una altitud promedio de $1300 \mathrm{msm}$ con temperaturas que varían entre $11^{\circ} \mathrm{C}$ y $33^{\circ} \mathrm{C}$, con un promedio de $24^{\circ} \mathrm{C}$. 
La provincia de García Rovira está conformada por 13 municipios siendo Málaga su capital, con temperaturas promedio que varían entre $14^{\circ} \mathrm{C}$ (Guaca y Cerrito) y $18^{\circ} \mathrm{C}$ (Málaga) y sus municipios tienen altitudes de $2220 \mathrm{msm}$ (Cerrito), 2235msm (Málaga) y $2401 \mathrm{msm}$ (Guaca).

\section{Participantes}

Se incluyeron como participantes menores de cinco años que fueron llevados a consulta de urgencias por una enfermedad respiratoria definida por la presencia de uno de los siguientes síntomas: congestión nasal, rinorrea, tos, dificultad para respirar o para deglutir. Los criterios de inclusión fueron: máximo cinco días de inicio de los síntomas, residencia en Santander sin haber salido del departamento los 14 días anteriores al inicio de los síntomas y edad menor de cinco años. Los niños fueron excluidos si recibieron antivirales para influenza o si tuvieron una enfermedad previa en los siete días anteriores al inicio de los síntomas. Para determinar el tipo de IRA se usó la clasificación del Programa de Atención Integrada de las Enfermedades Prevalentes de la Infancia (AIEPI-2012). Los criterios empleados para definir taquipnea también fueron tomados del AIEPI 2012.

\section{Ruta del estudio y recolección de muestras}

Una vez los cuidadores del niño dieron su consentimiento informado, se recolectaron los datos clínicos, epidemiológicos y del examen físico en un formulario elaborado para el estudio.

Las muestras fueron tomadas por personal previamente entrenado, usando hisopado nasofaríngeo con escobillón de rayón estéril, conservadas en medio de transporte viral (Vircell TM001) a $4{ }^{\circ} \mathrm{C}$, fueron trasladadas en menos de 72 horas al Laboratorio Central de Investigaciones de la Facultad de Salud de la Universidad Industrial de Santander donde se extrajeron los ácidos nucleicos con el kit comercial Gene-spin ${ }^{\mathrm{TM}}$ que fueron almacenados a $-20{ }^{\circ} \mathrm{C}$ hasta ser empleados.

Reacción en Cadena de Polimerasa con transcripción inversa (RT-PCR) multiplex para la identificación viral Se empleó amplificación por RT-PCR multiplex para detectar los virus con el test cualitativo Seeplex ${ }^{\circledR}$ RV15 OneStep ACE Detection (Seegene, Seoul, South Korea) que amplifica simultáneamente secuencias de ADN/ ARN específicas para 15 virus distintos. Mediante una prueba piloto el test fue validado a nivel local de acuerdo a las instrucciones dadas por el productor. La prueba tiene una especificidad que en promedio es mayor del $98 \%$, con sensibilidad mayor del $60 \%$ para la mayoría de virus (la sensibilidad reportada Coronavirus y Bocavirus es $24 \%$ y $25 \%$, respectivamente). Fueron efectuadas tres reacciones de amplificación, con su respectivo control interno y los iniciadores para la amplificación de 5 virus. Este programa de amplificación contó con 45 ciclos de $94{ }^{\circ} \mathrm{C}$ por 0,5 minuto, $60{ }^{\circ} \mathrm{C}$ por 1,5 minutos y $72{ }^{\circ} \mathrm{C}$ por 1 minuto. La amplificación se terminó con una extensión a $72^{\circ} \mathrm{C}$ durante 10 minutos y se visualizaron los amplificados en gel de agarosa al $2 \%$ coloreado con bromuro de etidio.

\section{Análisis estadístico}

Se realizó estadística descriptiva, calculando distribución de frecuencias por las variables edad, grupos de edad, sexo, procedencia, seguridad social y virus aislado.

\section{RESULTADOS}

La población de estudio correspondió a 64 menores de cinco años, de estos $57,8 \%$ niños y $26,6 \%$ menores de un año. La tabla 1 presenta las características sociodemográficas de la población de estudio.

Tabla 1. Condiciones sociodemográficas de la población de estudio, Santander 2012-2013.

\begin{tabular}{lcc}
\hline Característica & N & \% \\
\hline Sexo & & \\
Femenino & 27 & 42,19 \\
Masculino & 37 & 57,81 \\
Edad & & \\
Menor 1 año & 17 & 26,56 \\
1 año & 4 & 6,25 \\
2 años & 30 & 46,88 \\
3 años & 7 & 10,94 \\
4 años & 6 & 9,38 \\
Provincia & & \\
Comunera & 41 & 64,06 \\
García Rovira & 23 & 35,94 \\
Régimen de afiliación en salud & & \\
Contributivo & 10 & 15,63 \\
Subsidiado & 52 & 81,25 \\
Excepción & 1 & 1,56 \\
No afiliado & 1 & 1,56 \\
Estrato socioeconómico de la vivienda & & \\
Uno & 46 & 71,88 \\
Dos & 10 & 15,63 \\
Tres & 0 & 0,00 \\
Cuatro & 1 & 1,56 \\
Sin dato & 7 & 10,94 \\
Nivel educativo de la madre & & \\
Primaria & & \\
Secundaria & & \\
Universidad & 20 & 31,25 \\
\hline & 36 & 56,25 \\
& & 12,50 \\
\hline
\end{tabular}


La PCR-RT fue positiva en 24 casos (37,5\%). En el 8,3\% $(\mathrm{n}=2)$ de las muestras positivas se presentó co-infección por dos virus: Influenza B y Parainfluenza 4 en un caso y en el otro, Rhinovirus y Parainfluenza 1. De los casos positivos, $75 \%$ procedían de la provincia Comunera y $25 \%$ de la provincia de García Rovira. La positividad de las muestras fue distinta en las dos provincias: $43,9 \%$ en la Comunera y $26,1 \%$ en García Rovira.

Se identificaron 12 de los 15 virus buscados. Los virus identificados con mayor frecuencia fueron Rhinovirus (29\%), Parainfluenza 4 (20,8\%) e Influenza (12,5\%). La descripción de los virus aislados se encuentra en la tabla 2. Dado el número pequeño de la muestra, no fue posible realizar inferencias sobre la estacionalidad de cada virus.

Tabla 2. Virus identificados en las provincias Comunera y de García Rovira. Santander 2012-2013.

\begin{tabular}{|c|c|c|c|c|}
\hline \multirow{2}{*}{ Virus } & \multirow{2}{*}{$\begin{array}{c}\text { Provincia } \\
\text { Comunera } \\
\mathbf{N}\end{array}$} & \multirow{2}{*}{$\begin{array}{c}\text { Provincia de } \\
\text { García Rovira } \\
\text { N }\end{array}$} & \multicolumn{2}{|c|}{ Total } \\
\hline & & & $\mathbf{N}$ & $\%$ \\
\hline $\begin{array}{l}\text { Rhinovirus humano } \\
\mathrm{A} / \mathrm{B} / \mathrm{C}\end{array}$ & 5 & 2 & 7 & 29,1 \\
\hline Parainfluenza 4 & 5 & & 5 & 20,8 \\
\hline Influenza B & 2 & & 2 & 8,3 \\
\hline Influenza A & & 1 & 1 & 4,2 \\
\hline Adenovirus & 1 & 1 & 2 & 8,3 \\
\hline${ }^{a}$ VSR A & 1 & & 1 & 4,2 \\
\hline${ }^{a}$ VSR B & 1 & & 1 & 4,2 \\
\hline Metapneumovirus & 1 & & 1 & 4,2 \\
\hline Parainfluenza 1 & & 1 & 1 & 4,2 \\
\hline Coronavirus OC43 & 1 & & 1 & 4,2 \\
\hline $\begin{array}{l}\text { Coronavirus } \\
\text { 229E/NL63 }\end{array}$ & & 1 & 1 & 4,2 \\
\hline Parainfluenza 3 & 1 & & 1 & 4,2 \\
\hline Parainfluenza2 & & & 0 & 0 \\
\hline Enterovirus & & & 0 & 0 \\
\hline Bocavirus & & & 0 & 0 \\
\hline $\begin{array}{l}\text { Total aislamientos } \\
\text { virales }\end{array}$ & 18 & 6 & 24 & 100 \\
\hline
\end{tabular}

${ }^{a}$ VSR: Virus sincitial respiratorio

\section{DISCUSIÓN}

Este es el primer estudio que busca e identifica la presencia de un amplio número de virus respiratorios en provincias santandereanas. Los resultados muestran que hay una importante variedad de virus circulando en 243 las provincias Comunera y García Rovira de Santander. Al comparar con información no publicada de la Secretaría de Salud Departamental sobre aislamientos virales en niños en el 2013, solo hay un caso identificado de un niño de 5 años del Socorro con virus Influenza A. La Secretaría de Salud Departamental no tiene la posibilidad de identificar rutinariamente otros virus respiratorios diferentes a Influenza ni cuenta con PCR. En nuestro estudio, el virus de la influenza ocupó el tercer lugar en frecuencia. Al comparar con la cobertura de vacunación para influenza estacional en 2013 (datos de la Secretaría de Salud aún no publicados), se verifica que ésta fue relativamente baja en estas provincias (García Rovira: 39,8\% para menor de 1 año y $68,8 \%$ para 12 a 23 meses y en Comunera: $37,6 \%$ y $57,8 \%$ respectivamente). Esto indica que mejorar estas coberturas puede prevenir un importante número de infecciones respiratorias.

En el Departamento de Antioquia, la positividad reportada de las muestras en 2012 fue de 51\%. Esto incluye muestras procesadas por inmunofluorescencia (panel viral para Influenza A y B, Adenovirus, VSR y Parainfluenza 1,2 y 3) y otras por PCR-RT para estos mismos virus. Es de resaltar que el virus que predominó fue el VSR, seguido de Influenza A (no H1N1) y Parainfluenza 3. Sin embargo no se desglosa la información por edades ni municipios para excluir los datos correspondientes a la ciudad capital, Medellín, y poder establecer comparaciones con nuestro estudio ${ }^{3}$.

Una revisión de las muestras procesadas mediante PCR$\mathrm{RT}$ en las bases de datos del grupo de virología del Instituto Nacional de Salud, mostró que en el 2013 las muestras positivas fueron de $27,3 \%$ y entre el 2013 y el 2015 los virus más frecuentes fueron el VSR (53\%), el Influenza A (24\%), el virus de la enfermedad aleutiana $(12 \%)$ y el Metapneumovirus (7\%), pero estos datos no están discriminados por edades, ni zonas rurales y urbanas ${ }^{4}$.

En un estudio realizado en el estado Zulia de Venezuela entre febrero de 2005 y julio de 2006 para identificar etiología de IRA usando aislamiento viral e inmunofluorescencia directa para cuatro virus, se obtuvieron 102 muestras con identificación de virus en 46 de ellas (45\%). En 27 niños hasta los seis años de edad se identificaron Adenovirus, Influenza, Parainfluenza y $\mathrm{VSR}^{5}$. Los resultados de nuestro estudio muestran que estos cuatro virus circulan a los dos lados de la frontera colombo venezolana.

Se identificaron dos casos de infección simultánea por dos virus $(8,3 \%)$. Esta prevalencia es notoriamente inferior a la reportada en Chile donde la co-infección 
Etiología viral de infección respiratoria aguda en niños menores de 5 años en las provincias Comunera y García Rovira de Santander

reportada varía entre el $16 \%$ y $37 \%$ \%,7,8 y en España en donde se ha reportado hasta $62 \%$ de co-infección en niños hospitalizados ${ }^{9}$. En Colombia, un estudio que evaluó infecciones por VSR y adenovirus en menores de tres años hospitalizados, encontró infección simultánea en $4,5 \%$ de los pacientes ${ }^{10}$. No se halló alguna característica sociodemográfica o clínica particular ni mayor severidad de la IRA en los niños con co-infección; sin embargo, esto puede explicarse dado que el número limitado de aislamientos simultáneos no permite hacer comparaciones precisas entre niños con mono-infección y co-infección. A este respecto una reciente revisión sistemática y meta-análisis no encontró diferencias en severidad clínica entre las mono-infecciones y co-infecciones respiratorias virales, por lo cual el mayor riesgo de mortalidad observado en niños con co-infección viral aún requiere mayor investigación ${ }^{11}$.

Este estudio tiene algunas limitaciones. En primer lugar, el tamaño de la muestra dificulta hacer análisis de estacionalidad o relacionarlas con temporadas de infección respiratoria a nivel de las zonas evaluadas. De manera similar, los datos tampoco permiten hacer comparaciones con otras provincias Santandereanas ni establecer patrones de circulación con respecto a años anteriores. En este estudio no se realizó identificación de bacterias, las cuales pueden agregarse a infecciones virales previas o ser la causa de la infección respiratoria en los casos donde no pudo aislarse un virus.

Es de notar, la necesidad de contar con un monitoreo permanente de los virus circulantes en el departamento de Santander con técnicas de PCR-RT que permitan una mejor vigilancia epidemiológica de la IRA en menores de cinco años.

\section{CONSIDERACIONES ÉTICAS}

El Comité de Ética del Instituto del Corazón de Bucaramanga aprobó el protocolo de la investigación y el consentimiento informado de acuerdo a los estándares éticos de la Declaración de Helsinki (Acta No. 048 del 14 de abril de 2012). El consentimiento informado fue firmado por los cuidadores del paciente $\mathrm{y}$ todos los datos recolectados fueron confidenciales.

\section{DECLARACIÓN DE CONFLICTO DE INTERESES}

Los autores manifiestan que no existe ningún conflicto de intereses.

\section{AGRADECIMIENTOS}

A Oscar Téllez Santos, pediatra, por su colaboración para la realización del protocolo inicial de este estudio y a la Universidad Industrial de Santander y la Gobernación de Santander por la financiación de este proyecto.

\section{REFERENCIAS}

1. GBD 2013 Mortality and Causes of Death Collaborators. Global, regional, and national agesex specific all-cause and cause-specific mortality for 240 causes of death, 1990-2013: a systematic analysis for the Global Burden of Disease Study 2013. Lancet. 2015; 385(9963): 117-171. DOI: 10.1016/S0140-6736(14)61682-2.

2. Observatorio de Salud Pública de Santander. Indicadores Básicos, Situación de Salud en Santander 2013. Suplemento de la revista del observatorio de salud pública de Santander. 2013; 8(3): 32.

3. Secretaría Seccional de Salud y Protección Social de Antioquia. Análisis de la situación de salud, Vida saludable y enfermedades trasmisibles: Indicadores de enfermedad similar a la Influenza ESI, Vigilancia Centinela Antioquia. Medellín: Gobernación de Antioquia; 2012.

4. Barbosa J, Ospitia E, Malo D, Pulido P. Impacto de la circulación del virus de la influenza y otros virus respiratorios en Colombia, 2013-2015. Biomédica. 2015; 35(Supl. 1): 50-78.

5. Valero N, Larreal Y, Arocha F, Gotera J, Mavarez A, Bermudez J, et al. Viral etiology of acute respiratory infections. Invest Clin. 2009; 50(3): 359-368.

6. Escobar A M, Martínez F, Ceruti E, Díaz A, Vicente M, Farías P, et al. Etiology of acute lower respiratory tract infections in hospitalized infants: virologic studies. Rev Chil Pediatr. 1988; 59(6): 349-353.

7. Martínez $\mathrm{P}$, Cordero J, Valverde C, Unanue N, Dalmazzo R, Piemonte P, et al. Co-infección viral respiratoria en niños hospitalizados por infección respiratoria aguda y su impacto en la gravedad clínica. Rev Chil Infect. 2012; 29 (2): 169-174.

8. Palomino M A, Larrañaga C, Villagra E, Camacho J, Avendaño LF. Adenovirus and respiratory syncytial virus-adenovirus mixed acute lower respiratory infections in Chilean infants. Pediatr Infect Dis J. 2004; 23(4): 337-341.

9. Martínez-Roig A, Salvadó M, Caballero-Rabasco M, Sánchez-Buenavida A, López-Segura N, BonetAlcaina M. Coinfección vírica en las infecciones respiratorias infantiles. Arch Bronconeumol. 2015; 51(1): 5-9. 
10. Rodríguez C, Rodríguez DA, Cárdenas A, Quilaguy I, Mayorga L, Falla L, et al. Infección por Virus Sincitial respiratorio y por adenovirus en una población de niños colombianos menores de 3 años hospitalizados por infección respiratoria aguda baja. Rev Medica Sanitas. 2013; 16(2): 16-24.

11. Asner, S, Science M, Tran D, Smieja M, Merglen A, Mertz D. Clinical disease severity of respiratory viral co-infection versus single viral co-infection: A systematic review and meta-analysis. PLoS ONE. 2014; 9(6): e99392. 